\title{
DEBATE SOBRE O ENSINO RELIGIOSO NA CAPITAL PARANAENSE: ENTRE A TRIBUNA E A IMPRENSA (1922-1931)
}

RESUMO: Este artigo analisa as ações e os discursos promovidos pelos intelectuais católicos em defesa da presença do ensino religioso nas escolas públicas paranaenses no período circunscrito entre 1922 e 1931. Apoia-se no pronunciamento do deputado Alcidino Pereira, com o qual justificou seu projeto instituindo o ensino religioso facultativo nas escolas públicas, no parecer da Comissão de Constituição e Justiça do Congresso Legislativo do Paraná elaborado pelo deputado Azevedo Macedo, na resposta do autor do projeto ao parecer da Comissão e na revista católica $A$ Cruzada. Tais dados são analisados sob a perspectiva da história intelectual da educação, visando a restituir alguns dos sentidos da disputa entre católicos e anticlericais, ao longo da década de 1920 e início da década de 1930, sem esquecer o contexto nacional e internacional como pano de fundo desse movimento de discussão sobre a presença da cultura religiosa nos espaços escolares oficiais.

Palavras-chave: Intelectuais; Igreja Católica; Ensino Religioso.

\section{A DISCUSSION ON RELIGIOUS TEACHING IN THE CAPITAL CITY OF PARANÁ: BETWEEN THE TRIBUNE AND THE PRESS (1922-1931)}

ABSTRACT: This article analyzes the actions and speeches of catholic intellectuals when defending the teaching of religion in state schools of Paraná from 1922 to 1931. The article bases itself on deputy member Alcidino Pereira's pronouncement, which justified his project for the organisation of optional religious education in state schools. The article is also based on the opinion of the Constitutional and Judicial Commission of the Legislative Congress of Paraná organized by deputy member Azevedo Macedo on the reply given by the author of the project to the opinion of the Commission and on the Catholic magazine A Cruzada. The data is analyzed from the perspective of the intellectual history of education, intending to restore some meaning to the dispute between catholics and anticlericals during the 1920s and early 1930s without, however, neglecting the national and international context as the background to all the activity over the discussion about the presence of religious culture in official teaching establishments.

Keywords: Intellectuals; The Catholic Church; Religious Education.

\footnotetext{
* Doutor em Educação pela Universidade Federaldo Paraná (UFPR) e Professor do Programa de Mestrado em Educação da Universidade Estadual de Ponta Grossa (UEPG). E-mail: nmestrado@ig.com.br
} 


\section{Introdução}

Este artigo objetiva analisar as ações e os discursos dos intelectuais católicos em defesa do ensino religioso no estado do Paraná, no período circunscrito entre 1922 e 1931, privilegiando suas intervenções na imprensa católica e no Congresso Legislativo Paranaense. Em 1922, foi apresentado pelo deputado Padre Alcidino Pereira o Projeto n. 40, que visava a estabelecer o ensino religioso facultativo nas escolas públicas e nas instituições de ensino privadas subvencionadas pelo poder estatal paranaense. Em 1926, o grupo católico estabeleceu a revista A Cruzada, com circulação até 1931. Em 1931, o Ministro da Educação Francisco Campos, por meio do Decreto n. 19.941, instituiu o ensino religioso como disciplina facultativa para compor o currículo das escolas públicas brasileiras. A imprensa católica paranaense divulgou um conjunto de artigos em tom comemorativo pela inclusão dessa matéria no ordenamento jurídico brasileiro. A ênfase na imprensa e na legislação (Projeto de Lei/ Decreto Federal) justifica-se pelo sentido polêmico e circunstancial dos enunciados jornalísticos e jurídicos. Nesses termos, este artigo visa a captar os sentidos que o movimento da Igreja Católica assumiu na capital paranaense, operando uma análise não apenas da visão de mundo católica, mas principalmente da circulação dessa concepção entre o público leitor médioํ. O grupo católico paranaense buscava explicitar nos periódicos sua posição intelectual e política em defesa do ensino religioso nas escolas públicas, a fim de produzir um consenso sobre tal matéria. Além do mais, buscou materializar sua visão de mundo (cultura) em força política (legislação). Em termos sintéticos, esta narrativa traz à luz a ação cultural e política do grupo católico que postulava o ensino religioso nas escolas públicas.

\section{Ação do Deputado Pe. Alcidino Pereira na tribuna do parlamento paranaense}

Em março de 1922, Pe. Alcidino Pereira², na condição de parlamentar, apresentou o Projeto n. 40 ao Congresso Legislativo Paranaense, visando a instituir o ensino religioso facultativo nas escolas públicas e subvencionadas pelo estado do Paraná. A proposição desse projeto provocou forte debate entre os parlamentares. A imprensa curitibana, particular- 
mente aquela alinhada aos anticlericais (Comércio do Paraná, Diário da Tarde, Gažeta do Povo), endereçou muitas críticas à iniciativa do representante do clero.

Neste item, será analisado o confronto em torno desse projeto a partir do debate ocorrido no próprio Congresso Legislativo entre o parlamentar-autor e o relator da Comissão de Constituição e Justiça. A rigor, enfatizam-se três pronunciamentos: 1) Discurso com o qual o deputado Alcidino Pereira justificou seu projeto, instituindo o ensino religioso facultativo nas escolas; 2) Parecer da Comissão de Constituição e Justiça do Congresso Legislativo elaborado pelo deputado Azevedo Macedo; 3) Refutação do Parecer da Comissão de Constituição e Justiça ${ }^{3}$.

A mensagem do presente projeto apresentado ao Congresso Paranaense apregoava que "no edifício das escolas públicas ou subvencionadas poderá ser ministrado pelo professor ou por outrem o ensino religioso facultativo da religião da maioria dos habitantes da localidade, aos alunos cujos pais não se opuserem" (PROJETO n. 40..., 1922, p. 1). O pronunciamento do deputado Alcidino Pereira, que visava a apresentar e justificar o projeto entre os demais parlamentares, inicia com a explicitação da diferença entre instrução e educação. Na acepção desse parlamentar, a instrução enfatizava a preparação técnica. Já a educação deveria cuidar da formação integral do indivíduo. Tal assertiva ganha contornos precisos nas palavras do referido deputado: "a instrução deve cultivar a cabeça não descurando o coração. É preocupado com a formação completa da criança que eu ocupo agora esta tribuna, na defesa de um princípio que não é partidarismo, na exposição de uma ideia que não é pessoal” (p. 5).

A primeira argumentação do Pe. Alcidino Pereira está associada à tese de autoridade. Fez menção aos discursos de políticos franceses que da tribuna enfatizavam o postulado de que não há instrução sem educação, nem educação sem ensino moral religioso (BARDOUX, 1880); é necessário que a atmosfera geral da escola seja moral e religiosa (Guizot); não é a instrução que moraliza, é a educação e, principalmente, a educação religiosa (Cousin); o ensino religioso deve penetrar toda a instrução para ser eficaz e a criança deve viver sempre em uma atmosfera religiosa (RIBOT, 1903). Fez referência também a juristas e autoridades políticas brasileiras que se alinhavam ao catolicismo, particularmente Pedro Augusto Lessa, Rui Barbosa e Augusto Viveiros de Castro. Tal estratégia visava a mobilizar o argumento de autoridade para fundamentar sua pro- 
posição, pois sabia que a bancada não-católica se manifestaria contrariamente. Esse argumento reafirma a cosmovisão transcendental, uma vez que postula a superioridade da educação sobre a instrução, da moral sobre a ciência e da religião católica sobre a moral.

O segundo argumento postulado para fundamentar a apresentação do referido projeto é de natureza filosófico-jurídica. Trata-se da liberdade de consciência, a qual não poderá ser obliterada pelo Estado. No entendimento de Alcidino Pereira, “[...] o Estado não pode impedir nem dificultar, que venho defender o ensino religioso facultativo nas escolas oficiais aos alunos cujos pais não se opuserem" (p. 6). A contraposição é em relação à exclusão da religião das escolas. Para ele, a retirada do ensino religioso das escolas (1891) não implicava a concessão de que as instituições de ensino professassem "[...] a irreligião e a incredubilidade [...]" (p. 6). Em interlocução com Rui Barbosa, asseverava: "foi a liberdade religiosa, de acordo com a hermenêutica americana, que nós escrevemos na Constituição Brasileira" (p. 6). A tradição norte-americana autorizava o ensino religioso em horário que não coincidisse com as atividades escolares regulares. Ou seja, a proposição de Alcidino Pereira indicava a inclusão do ensino religioso como disciplina complementar.

Alcidino Pereira criticava as autoridades políticas e intelectuais que preconizavam uma República brasileira nos moldes da francesa (anticlericalismo de Jules Ferry). Em oposição a esses grupos, recuperava o sentido da constituição norte-americana: "é assim que se pratica nos Estados Unidos essa neutralidade entre as religiões, que nunca encontrou ali como profissão nacional de agnosticismo ou do materialismo do Estado, senão [...] do seu respeito entre as várias denominações religiosas" (p. 6). Emendava: "a Constituição brasileira bebeu ali, não em França. Não em França, mas ali, é que lhe havemos de ir buscar as lições, as decisões, as soluções - irritantes, racionárias, violentas na política francesa - e na americana, eqüitativa, benéfica, pacificadora” (p. 6). A tática desse deputado é pragmática: para defender a tese católica, dialoga com autores franceses que postulam a reação clerical; ao combater a constituição francesa anticlerical, mobiliza a constituição norte-americana.

$\mathrm{Na}$ avaliação do deputado católico, o laicismo escolar proferido pelas autoridades políticas brasileiras consistia em uma cópia da intolerância e do anticlericalismo francês. $\mathrm{Na}$ sua exposição, relatava que Maurício Barrés (1910) denunciou que a política francesa não era neutra, mas anti- 
católica. Outra vez, fez alusão à experiência norte-americana, ao destacar a observação do bispo de Boston: "as nossas instituições [norte-americanas] estabelecem, realmente a separação, e sobre estabelecê-la a protegem, ao passo que, em França, ao revés, a separação nos parece um nome destinado a encobrir a situação exata ocultando sob um pretexto a guerra religiosa" (p. 7). A aproximação entre as constituições brasileira e norte-americana foi a base principal para propor seu projeto. Em nome da liberdade de consciência, o projeto foi apresentado ao Congresso paranaense, pois, na avaliação de Alcidino Pereira, "a neutralidade em matéria filosófica ou religiosa é um absurdo. A neutralidade escolar como entendem alguns viola o princípio de liberdade de consciência" (p. 9).

O terceiro argumento de defesa do projeto refere-se ao recurso à exemplaridade, no qual sustentava que "o exemplo de nações civilizadas vem em argumento de minha tese” (p. 11). Ele se referia à Alemanha, à Inglaterra, à Holanda, à Bélgica, à Itália, à Suíça, à Rússia, à Espanha, à Escandinávia, aos Bálcãs e à América Latina, com exceção do México. Fez alusão aos estados de Santa Catarina e Minas Gerais, que já tinham implantado o ensino religioso nas escolas públicas ${ }^{4}$.

No final do seu discurso de justificativa da proposição, o deputado asseverava que "o meu projeto se baseia nos moldes dos que existem na matéria, em diversos lugares [...]" (p. 12). A rigor, "facultativo para que seja respeitada a liberdade de consciência; aos alunos cujos pais não se opuserem, para que sejam respeitados os direitos dos pais; da religião da maioria dos habitantes da localidade" (p. 12). Seu projeto de lei foi proposto em nome do regime democrático. $\mathrm{Na}$ sua concepção, "num regime democrático onde predomina a lei da maioria, não respeitar esta cláusula, seria ao meu ver a anarquia, a confusão, a desordem" (p. 12).

Tal projeto recebeu fortes críticas do deputado Azevedo Macedo, relator da Comissão de Constituição e Justiça. O parecer foi proferido no dia 23 de março de 1922, no qual o relator iniciou seu pronunciamento historiando a relação entre poder civil e poder eclesiástico no Império brasileiro, destacando "o ensino da religião católica, como parte essencial dos programas do curso das escolas públicas primárias” (p. 13). A seguir, Azevedo Macedo mobilizou o argumento da legalidade ao postular que, com a República, foi estabelecida a separação entre Estado e Igreja, ao determinar, no artigo primeiro do Decreto n. 119 de 7 de janeiro de 1890: 
É proibido à autoridade federal, como a dos Estados federados, expedir leis, regulamentos ou atos administrativos, estabelecendo alguma religião, ou vedando-a a criar diferenças entre os habitantes do país ou nos serviços sustentados a custa do orçamento, por motivo de crença ou opiniões filosóficas ou religiosas (p. 13-14).

O parlamentar seguiu sua argumentação ao fazer alusão à Constituição da República, particularmente ao artigo 72: "todos os indivíduos e confissões religiosas podem exercer pública e livremente o seu culto, associando-se para esse fim e adquirir bens, observadas as disposições do direito comum" (p. 14). No parágrafo sexto do referido artigo, decretava que "será leigo o ensino ministrado nos estabelecimentos públicos” (p. 14). O relator destacou o parágrafo sete do mesmo artigo: "nenhum culto ou Igreja gozará de subvenção oficial, nem terá relações de dependência ou aliança com o Governo da União ou dos Estados" (p. 14). $\mathrm{Na}$ avaliação de Azevedo Macedo, "expor simplesmente a situação jurídico-constitucional natural das religiões no Brasil, é já argumentar contra o projeto $\mathrm{n}^{\circ} .40$ " (p. 14). Na sequência, argumentou que "é absolutamente inconstitucional e, por isso, inadmissível [...] o projeto $\mathrm{n}^{\circ} .40$ apresentado pelo ilustre deputado Padre Dr. Alcidino Pereira [...]" (p. 15). Tal argumentação sustentava que o referido projeto "contravém o princípio geral da liberdade religiosa ou da igualdade entre as religiões, em uma das suas manifestações capitais, - a do ensino público necessariamente leigo" (p. 15). Em tom enfático, asseverava o relator: "é imperativa a disposição constitucional quando diz será leigo o ensino ministrado nos estabelecimentos públicos". É também “imperativa ainda quando proíbe as relações de dependência ou aliança de qualquer culto ou igreja com o Governo da União ou dos Estados" (p. 15).

Posteriormente, ao modo do deputado Alcidino Pereira, o relator Azevedo Macedo fez alusão ao argumento de autoridade, particularmente ao apresentar a avaliação dos pareceres de Rui Barbosa, nos quais destacava que "obrigar à escola e fazer dela a agência de propaganda de uma seita é cometer a suprema violência contra a humanidade e o direito". Apregoava também que "o Estado não tem outra alternativa razoável senão subsidiar indiferentemente as escolas de todas [as] denominações religiosas, ou negar ao ensino religioso todo subsídio oficial” (p. 15). Além disso, na avaliação de Rui Barbosa, segundo Azevedo Macedo, para organizar um sistema de ensino de massa há duas alternativas: "uma, se, não prescindiu da religião, é 
modelar um plano que subvencione todas as religiões; a outra consiste em adotar a instrução leiga, deixando o ensino religioso aos esforços individuais" (p. 15). Se o deputado católico se referia aos pronunciamentos de Rui Barbosa (proferidos na década de 1910) para defender o ensino religioso nas escolas oficiais, o relator destacava a intervenção dessa mesma personalidade (pareceres de 1882). Nos pareceres de Rui Barbosa, definiu-se que cada liderança ensinaria religião nos espaços das escolas oficiais, ou seja, de modo diferente do projeto n. 40, Rui Barbosa apregoava o ensino de todas as religiões, e não a religião da maioria. $\mathrm{Na}$ acepção de Azevedo Macedo, a proposição de Rui Barbosa tinha um caráter liberal em pleno regime monárquico, não obstante, na República, também seria inadmissível por ser dissonante com a Constituição de 1891.

O terceiro recurso argumentativo de Azevedo Macedo consistia em atacar partes específicas do projeto de Alcidino Pereira. O primeiro aspecto que mereceu destaque foi: o ensino religioso deve ser ministrado pelo professor ou por outrem. Indagou-se o relator quem é outrem? Seria o ministro da religião? O professor não se transformaria em um catequista? O segundo aspecto diz respeito aos exemplos dos estados de Santa Catarina e Minas Gerais. Para Macedo, “exemplo é não de imitar, mas de lamentar e combater, porque contravém a Constituição Federal em um dos seus pontos essenciais" (p. 17). O terceiro aspecto se refere ao direito da igualdade, que é negado pelo presente projeto, pois, em nome da maioria religiosa, seria sacrificado o direito das minorias.

A quarta argumentação tem caráter filosófico, pois discute a tese católica de que escola sem religião não educa, apenas instrui. "Falsíssimo conceito, inverdade palpável. A verdadeira escola pública primária é essencialmente educativa”, afirma Azevedo Macedo (p. 18-19). Não há associação necessária entre religião e moral. É possível uma moral racional, portanto laica, sustenta o relator. Recupera de Rui Barbosa uma passagem dos pareceres: "não ensinando o credo religioso, incumbe, todavia, à escola o mais estrito dever de inspirar os sentimentos morais" (p. 19). Igualmente, apropria-se da afirmação de Lastarria: "a verdade da existência de uma moral universal não depende de nenhum dogma religioso e, por isso mesmo, a verdade da analogia da moral que ensinam e praticam todas [as] religiões” (p. 20). A oposição filosófica se dá entre uma concepção transcendental de existência (racionalidade religiosa/teológica) e uma acepção imanente de existência (racionalidade laica). 
As observações finais do parecer da Comissão de Constituição e Justiça arrematam que a educação religiosa é livre nos lares, nas escolas particulares e nos templos. Ao Estado é obrigatório garantir o direito à liberdade religiosa, evitando arbitrar favoravelmente a algumas em detrimento de outras e garantindo a tolerância entre os diferentes credos. Em termos conclusivos, "a Comissão de Constituição e Justiça é de parecer que o projeto $n^{\circ} .40$ não pode ser adotado pelo Congresso, por que contraria disposições expressas e imperativas da Constituição Federal” (p. 20).

Na sessão de 28 de março de 1922, o deputado Alcidino Pereira ocupou a tribuna para avaliar o parecer da Comissão de Constituição e Justiça. Em primeiro lugar, acusou os membros da Comissão de exararem o parecer em contraposição à Igreja Católica. Em segundo, considerou irrelevante a recuperação da Constituição para postular a ilegalidade do projeto. Ele condenou o silêncio da referida comissão sobre suas observações referentes à constituição norte-americana, o que demonstra má vontade em discutir a matéria.

Em contraposição ao argumento de autoridade oriundo dos pareceres de Rui Barbosa, Alcidino Pereira faz referência aos comentários revisionistas feitos em 1910. O deputado católico recupera de Rui Barbosa a afirmação de que

quase trinta anos há, pois, que, ocupando-me com a organização geral do ensino, planeava eu, em termos rigorosos, a associação do ensino religioso à escola leiga [laica], mediante o ingresso franqueado, nos edifícios escolares, aos ministros do culto, e para o magistério a palavra divina" (PROJETO n. $40 \ldots, 1922$, p. 22).

Emendava que "bem vedes que há mais de trinta anos apostolizo a liberdade religiosa, como nos Estados Unidos” (p. 23). Após a exposição dos comentários de Rui Barbosa, Alcidino Pereira enfatiza que tal intervenção foi pronunciada "em 20 de fevereiro de 1910 e a do parecer é de 1882” (p. 23). Se ambos exploram o argumento de autoridade de Rui Barbosa, a estratégia discursiva do Pe. Pereira é invalidar a interpretação de Azevedo Macedo e ressaltar a superioridade da sua compreensão.

$\mathrm{Na}$ sequência do pronunciamento, Pe. Alcidino Pereira se contrapôs aos argumentos explorados pelo deputado Azevedo Macedo, particularmente a associação entre ensino religioso facultativo e ensino religioso católico, a descaracterização da condição necessária da religião para 
educar e instruir, a negação da democracia como direito da maioria, a inconstitucionalidade das legislações catarinense e mineira, que autorizaram o ensino religioso nas escolas públicas. Em nosso entendimento, tais aspectos centralizam a intervenção do deputado católico. A primeira preocupação objetiva desmantelar a tese da Comissão de que o projeto, sob o pano de fundo do ensino religioso facultativo, visava a implantar a educação religiosa católica nas escolas oficiais. A segunda investida se refere à reafirmação da indissociabilidade entre moral e religião (educação e instrução): "repito não há moral verdadeira sem Deus e provo: a moral supõe uma lei e uma norma para a ação comum e como poder-se-ia obter essa norma ou lei geral sem partir de um Ser Superior?” (p. 27). A terceira discussão está centrada na concepção de democracia como expressão do direito da maioria: “[...] se para tudo exige a maioria porque neste caso particular [ensino religioso] há de haver desigualdade?” (p. 27). Por fim, rechaça o postulado de que as legislações de Minas Gerais e Santa Catarina, bem como seu projeto, seriam inconstitucionais, ao indicar interpretações favoráveis de vários juristas à implantação do ensino religioso facultativo nas escolas oficiais.

Em termos conclusivos, o deputado Alcidino Pereira reconhecia a derrota política de sua proposição. No entanto, visava a caracterizar uma representação desinteressada a sua ação no Parlamento Paranaense: "vos devo dizer que procurei dentro desta Casa cumprir o meu dever, não me conduzindo por interesses pessoais, paixões partidárias ou conluios menos dignos" (p. 35). Em alusão à condição de mártir, sustentava que "lá fora me atiraram pedras; declaro que essas pedras não me atingiram, porque conservei-me superior, no plano que a minha educação ordena e a minha posição exige "5" (p. 35). Emendava o deputado católico: "vou recolhê-las, porém, e lá em terra estranha com elas vou fazer um altar e diante dele pedir a Deus pela grandeza do Paraná” (p. 35).

O debate entre o proponente do projeto e a Comissão se explicita em nome da verdade e de uma objetividade jurídica. Nesse aspecto, as observações desses parlamentares se posicionavam no próprio campo jurídico, o qual "é o lugar de concorrência pelo monopólio de dizer o direito, quer dizer, a boa distribuição ou a boa ordem [...]" (BOURDIEU, 2002 , p. 212). Em tal disputa "se defrontam agentes investidos de competência ao mesmo tempo social e técnica que consiste essencialmente na capacidade reconhecida de interpretar [...] um corpus de textos que con- 
sagram a visão legítima, justa, do mundo social" (p. 212). Os agentes (deputados) promoviam suas intervenções em nome de uma objetividade, entretanto, implicitamente continham os porta-vozes de seus discursos. A porta-voz do discurso de Alcidino Pereira era a Igreja Católica. O portador do discurso da comissão era o grupo anticlerical curitibano. A disputa não era, em si, pelo monopólio de dizer o direito, mas, em nome do direito, fazer valer as cosmovisões desses grupos sociais.

\section{Imprensa católica:}

\section{espaço de criação de consenso sobre 0 ensino religioso}

Na segunda metade da década de 1920, o grupo católico estabeleceu a Revista $A$ Cruzada, na qual veiculou seu posicionamento políticopastoral em defesa do ensino religioso nas escolas públicas. Nesse período, a estratégia da Igreja Católica consistiu em organizar o laicato católico paranaense, ou seja, sua ação vislumbrava a consolidação de uma visão de mundo entre parcela significativa da juventude curitibana, particularmente aquela que apresentava potencialidade para ocupar as esferas culturais e políticas do estado do Paraná. Apropriando-nos do conceito de poder simbólico de Pierre Bourdieu, é possível afirmar que o movimento da Igreja Católica visava a dirigir a elite intelectual curitibana. Em outros termos, se na arena política (parlamento) o grupo católico sofria derrotas, na esfera cultural buscava combater os anticlericais e postular sua doutrina confessional.

Da imprensa os católicos defendiam a necessidade de inclusão do ensino religioso no currículo escolar. Nessa cruzada pelo ensino religioso, o laicato católico fazia menção à iniciativa de Minas Gerais como principal exemplo a ser seguido pelos demais estados brasileiros. $\mathrm{Na}$ avaliação dos jornalistas no estado de Minas Gerais, "nos estabelecimentos de ensino mantidos pelo Estado, é permitida a instrução religiosa, dentro do horário escolar, por um espaço de tempo nunca superior a cinqüenta minutos por dia, e não mais de três vezes por semana" (A CRUZADA, nov. 1929, p. 325).

A imprensa tornou-se o espaço por excelência para divulgar a posição dos católicos. A rigor, a defesa da presença do pensamento católico nas diferentes esferas da sociedade brasileira ocorria em diferentes 
ambientes intelectuais, como, por exemplo, no Centro Dom Vital, na Associação Brasileira de Educação (ABE). Nas Conferências Nacionais de Educação da ABE, os representantes dos católicos apresentavam teses que propunham a necessidade da educação religiosa nas escolas públicas, embora tais proposições tenham sido recusadas total ou parcialmente pelos congressistas. A esse respeito afirma Carvalho:

O fracasso da tentativa do grupo católico de incluir a formação religiosa no currículo escolar foi compensado por estratégia que consistiu na apresentação de moção de aplauso ao governo de Minas por medida, que acabara de tomar, permitindo o ensino religioso nas escolas públicas primárias, no horário escolar, sem caráter obrigatório (CARVALHO, 1998, p. 334).

A ação que visava à inclusão do ensino religioso nas escolas públicas expressava um aspecto da disputa entre católicos e laicos, católicos e anticlericais, católicos e outros grupos religiosos (espíritas, protestantes, etc.). Para Carvalho, o retorno do ensino religioso nas escolas oficiais não garantia a vitória dos católicos sobre os anticlericais, pois, "confinado no âmbito de uma disciplina facultativa, o ensino religioso tinha um papel marginal na formação que a escola viesse a ministrar" (p. 335). A autora sustenta que, mesmo que o ensino religioso fosse estendido aos demais estados do Brasil, não implicaria a vitória do catolicismo. Os católicos sabiam disso, ou melhor, tinham conhecimento de que havia uma questão mais complexa, a necessidade de vigiar o laicismo, cuidando para que não avançasse para outras esferas públicas. Tal observação é reiterada por Carvalho, ao afirmar que "a defesa do patriotismo católico implicava vigilância contra o avanço de valores leigos que se insinuavam por frentes diversas, deslocando a questão religiosa para o campo mais amplo" ( $\mathrm{p}$. 335). O que os católicos pretendiam não era apenas o retorno do ensino religioso nas escolas públicas, mas a constituição de uma nação catolicizada. Desse modo, a inclusão da educação religiosa no currículo das escolas públicas representaria um avanço parcial.

A imprensa católica paranaense veiculava termos do léxico liberal para defender o retorno do ensino religioso às escolas públicas. O primeiro termo a ser incorporado foi liberdade de consciência. Os jornalistas católicos debatiam acerca do próprio entendimento desse conceito. A primeira observação consiste em desconstruir o entendimento de liberdade de consciência postulado pelos defensores do ensino laico. Tal grupo 
era denominado de acatólicos pelo grupo paranaense. É interessante indicar que os defensores do laicismo eram definidos com substantivos e adjetivos negativos. Por exemplo, "mobilizam-se os acatólicos brasileiros para abrir luta contra a iniciativa de alguns prelados nossos, visando um honroso acordo entre a Igreja e o Estado, para o bem comum" (A CRUZADA, 4 maio 1931, p. 01). Ao contrário, a autodenominação dos católicos era adjetivada positivamente. Os católicos movem-se por acordos nobres, honrosos, supremos, coletivos. Os acatólicos agem por projetos sem nobreza, desonrosos, individualistas. $\mathrm{Na}$ acepção do laicato católico, “os adversários indignos do catolicismo levantam o seu brado de protesto em nome da liberdade de consciência. Não querem Deus nas escolas, não querem Deus nos quartéis, não querem Deus nos tribunais, não querem Deus" (A CRUZADA, 4 maio 1931, p. 01). Além disso, asseveram os católicos, "querem uma educação atéia, querem um exército ateu! Santo Deus, e tudo isto em nome da liberdade de consciência!” (A CRUZADA, 4 maio 1931, p. 01). Os grupos combatidos pelos católicos eram denominados genericamente de "adversários", "indignos". Essa tendência explicita a retórica em agrupar todos os defensores do laicismo como inimigos do catolicismo. A rigor, os próprios católicos não constituíam um grupo, isto é, entre eles existiam posições divergentes. Não obstante, na imprensa, os católicos se expressavam no coletivo (representante da verdade católica) e reduziam todos os demais grupos a termos comuns (acatólicos/adversários indignos do catolicismo).

$\mathrm{Na}$ avaliação dos jornalistas católicos, a ação dos críticos do clericalismo expressa a própria liberdade de consciência. "Sois livres para continuardes com os olhos fechados ante a luz da verdade, para continuardes na triste faina de propagar os vossos erros lamentáveis, para continuardes a seduzir os incautos que se deixam apanhar nas malhas das vossas falsidades" (A CRUZADA, 4 maio 1931, p. 01). Porém, a atuação desse grupo explicita uma grande contradição: "o que tão [enfaticamente] pretendes em nome da liberdade de consciência é o mais ousado atentado à liberdade de consciência de uma nação católica" (A CRUZADA, 4 maio 1931, p. 01). Essa passagem explicita as diferentes compreensões do conceito de liberdade de consciência. Na tradição católica, a liberdade é pensada sob a luz de uma visão de mundo transcendental. Na concepção liberal laica, é entendida sob o prisma de uma visão de mundo imanente. Para os católicos, a liberdade está atrelada à experiência histórica de um 
povo. Nesse sentido, em nome da história católica do Brasil, o grupo defendia o direito da permanência das ideias católicas no interior das escolas e de outras instituições. O laicato católico usou o argumento histórico para sustentar que "quase a totalidade da nação brasileira é católica, e como tal assiste-lhe, o sagrado direito de ter o governo católico. Negarlhe este direito, como inconscientemente o fazeis, constitui uma agressão insólita à liberdade de consciência de todo o povo" (A CRUZADA, 4 maio 1931, p. 01). Liberdade se expressa no direito da maioria. No Brasil, os católicos faziam defesa desse argumento. $\mathrm{Na}$ China, por exemplo, postulavam a liberdade aos grupos minoritários, pois, naquele país, o catolicismo tinha fraca presença.

Os escritores da imprensa católica paranaense não aceitavam a proposição de que governantes defendessem ideias laicas numa nação onde a maioria professava o catolicismo. Para eles, o que os anticlericais pregavam como liberdade de consciência era o ideário de um reduzido número de pessoas. No seu entendimento, isso não era liberdade de consciência, mas um atentado, na sua denominação, à verdade. O grupo condenava a separação entre nação e governo.

Segundo Cury, os católicos acreditavam que:

A coexistência do laicismo nas escolas oficiais com o ensino religioso nas escolas privadas é duplamente injusto: primeiro, porque o ensino religioso é direito intangível das consciências e garantia para a vida moral do país. Segundo, porque oneraria duplamente a maioria católica, que além de custear a escola pública pelos impostos, deveria arcar com o ônus do ensino privado a fim de estar em paz com a sua consciência (p. 161).

Por outro lado, na avaliação dos anticlericais ,"o argumento de 'maioria católica' não é convincente, especialmente caso se vier a considerar os aspectos conscientes e qualitativos da opção religiosa por parte do grande número dos que se dizem católicos” (p. 161).

O posicionamento católico se manifestava na imprensa com muita clareza. Tal postura visava a construir um consenso de que seria "um dever da futura constituição, reconhecer e prestigiar a Igreja Católica” (A CRUZADA, 4 maio 1931, p. 01-02). Sob que argumento os católicos decretavam esse dever? Em nome da ordem sobrenatural da condição humana. "O governo brasileiro, em seu próprio interesse, deve professar a religião católica, por quanto um Estado que não reconhece os 
direitos de Deus e que terá aos seus olhos súditos a esperança da felicidade eterna, cava a sua ruína” (A CRUZADA, 4 maio 1931, p. 01-02). Figurava nesse enunciado a defesa de um projeto moderno em comunhão com a tradição, com o pensamento religioso, bem como a contraposição ao modelo de modernidade oriundo do movimento iluminista francês e da Revolução Francesa, nos quais se pretendeu constituir um etos iluminado apenas pela racionalidade científica. Se, no plano filosófico (dever ser), foi anunciado um projeto societário laico, no transcorrer histórico (ser), tal proposição enfrentou a contraposição de diferentes grupos e instituições, entre os quais a Igreja Católica.

A tática do laicato católico era desconstituir o capital cultural dos anticlericais, particularmente negar ao discurso deles o compromisso com a verdade (saber). Além disso, atrelar a eles a preocupação meramente com o poder. A si mesmos, os católicos adjetivavam a condição de guardiões da verdade. Aos anticlericais encetavam a noção de invasores dos templos sagrados. Com terminologias diferenciadas, reproduziam o confronto grego entre socráticos (lógicos/metafísicos) e sofistas (retóricos).

Segundo Cury, os católicos acreditavam que:

A adoção da escola leiga, num país católico, é a adoção da escola anticatólica e fere os princípios do próprio liberalismo que o Estado defende. Nesse caso, a família católica é ofendida e sua consciência é obrigada a fundar escolas particulares, a fim de salvaguardar os interesses do ideal religioso. A neutralidade só existe na teoria, na prática, ela cai no laicismo pedagógico. E escola sem religião equivale a escola contra a religião (CURY, 1988, p. 154).

A religião católica atribuía a si mesma a missão de formar os indivíduos com a finalidade de salvar o Brasil. Reiteramos que a disputa entre católicos e anticlericais se expressa no plano do conhecimento (saber). Do ponto de vista ontológico, é muito difícil definir quais conhecimentos deveriam compor o escopo curricular das escolas, pois, em última instância, a escolha perpassa pelo poder de definir quais conhecimentos são importantes à formação das novas gerações. $\mathrm{O}$ argumento católico de que o ensino religioso é tão importante quanto o ensino de ciências e filosofia é defensável do ponto de vista lógico. O que legitima a presença da educação física, da história, da geografia, da matemática, da biologia, da química, da física e deslegitima a inclusão do ensino religioso? Não há legitimidade lógica. A legitimidade está fundada no capital político dos 
grupos que defendem esses saberes. O projeto moderno (utopia) se constitui na medida em que dessacraliza o saber metafísico/teológico. $\mathrm{Na}$ mesma medida em que dessacraliza a metafísica católica, se sacraliza o saber científico. O grupo que melhor expressar sua concepção de mundo garantirá suas formas simbólicas no processo de conformação do sistema jurídico e do sistema das relações sociais. É nesse sentido que interpretamos que a ação do grupo católico - engajado nas arenas culturais e políticas - objetivava manter a presença do etos religioso-católico na sociedade contemporânea.

No editorial de um de seus periódicos, o laicato católico manifestava o sentido que atribuía ao conceito de liberdade. "Liberdade é a faculdade que tem o homem de governar e dirigir as suas ações" (A CRUZADA, 21 jul. 1931, p. 01). Não obstante, tratava de impor os limites a tal definição ao asseverar que "há os seus excessos, há os seus desvios, suas interpretações viciosas, que estragam por completo a noção desta faculdade do espírito humano" (p. 01). Historicamente, na avaliação dos jornalistas católicos, "desde o século XV que os inimigos do Cristo têm empregado todo o poder e toda a força desta palavra com o fim exclusivo de aluir os fundamentos da Igreja” (p. 01). Os eventos históricos que materializaram a denominada interpretação viciosa foram Renascimento, Reforma Religiosa, Revolução Francesa e Socialismo Bolchevista. Em nome da liberdade, os homens alteraram a ordem das coisas. "A religião foi banida de todas as esferas da atividade humana; a soberania do povo substituiu a de Deus; as constituições e os códigos renegaram de todo o espírito do catolicismo por isso a sociedade caminha para as bordas da subversão" (p. 01).

A compreensão de liberdade encerra uma diferença diametral entre católicos e anticlericais. Para o grupo católico, "a verdadeira liberdade pressupõe uma legislação superior, uma força que coíba os maus instintos, e esta potência espiritual é a lei divina, eternamente gravada na consciência humana. A verdadeira liberdade consiste na atuação da vontade humana dentro das leis divinas" (A CRUZADA, 21 jul. 1931, p. 01). Para os jornalistas católicos, "a liberdade de consciência e de pensamento não é, nem pode ser, privilégio dos inimigos da Igreja; nós católicos, a queremos também para nós e procuraremos garanti-la contra os ataques dos que no-la quiserem arrebatar" (A CRUZADA, 19 abr. 1931, p. 01).

Se o grupo católico estava intimamente ligado ao campo pedagógico, é preciso dizer que o seu ideário educativo versava principalmen- 
te sobre a importância da formação religiosa, pois a formação moral, cívica e intelectual do indivíduo estava condicionada a ela. O grupo católico entendia que a educação religiosa era uma necessidade para a formação das novas gerações. Esse argumento estava presente nos documentos de Roma, quando afirmavam que a educação escolar deveria ser continuidade da educação familiar. Era preciso que a escola se responsabilizasse pela formação religiosa, alicerce da formação moral do ser humano. Essa tarefa foi pensada e orientada pela hierarquia católica para começar pela formação de uma elite intelectual. Conforme Romualdo Dias (1993), o alto clero da Igreja Católica criou uma série de estratégias para atingir os variados grupos de católicos. A necessidade premente era constituir um grupo capaz de lutar em defesa dos interesses da igreja. Essa realidade foi sentida pelos católicos, segundo Cury, quando reconheceram "que não influíram nos destinos da nação desde a Constituição de 1891 e sua Reforma em 1926, porque não possuíam homens habilitados para tal. E a causa foi a falta de instrução natural, moral e religiosa da sociedade" (CURY, 1988, p. 61-62).

No ambiente de Reforma Constitucional de 1926, o grupo católico paranaense se manifestou com bravura em defesa da inclusão do ensino religioso nas escolas públicas. José de Sá Nunes ${ }^{6}$, um dos principais representantes do laicato católico na imprensa, declarava:

Faz hoje 35 anos que foi estabelecida, decretada e promulgada pelos representantes do povo brasileiro a Constituição da República dos Estados Unidos do Brasil. Ela passa hoje por uma reforma que, por iniciativa do Congresso Nacional, muito profícua seria, se consultasse de verdade os interesses do povo brasileiro. Também a Constituição do Estado do Paraná ainda este ano será reformada (A CRUZADA, mar. 1926, p. 04).

$\mathrm{Na}$ avaliação de Jamil Cury (1996, p. 82), "várias tentativas [de reforma constitucional] foram feitas, mas nenhuma com sucesso. A revisão constitucional foi encaminhada em pleno estado de sítio, em junho de 1925, tendo sido concluída em 07/09/1926”. A revisão constitucional consistiu na apresentação de 76 emendas "versando sobre os mais diferentes assuntos" (CURY, p. 82), entre elas a que visava a reintroduzir o ensino religioso. Não obstante, observa Cury (p. 83) que o "capítulo específico deste relatório de pesquisa - só não passou por uma diferença de 11 votos”. O deputado Plínio Marques apresentou duas emendas, uma 
delas objetivava introduzir o ensino religioso facultativo nas escolas públicas; a outra buscava estabelecer a Igreja Católica Romana como religião oficial do Brasil.

As emendas propostas pelo deputado, representante da bancada católica, foram muito criticadas pelo grupo defensor da escola laica. A derrota na esfera política forçou a Igreja Católica a mobilizar seu exército a lutar em outras trincheiras, particularmente na imprensa. Nesse sentido, a defesa do ensino religioso nas escolas foi enfatizada pela revista $A$ Cruzada, ao fazer referência ao debate da Primeira Conferência Nacional de Educação (1927) promovida pela ABE.

No primeiro Congresso de Educação realizado na nossa capital, vozes houve entre os que no ensino continuam a nobre Missão dos pais que se ergueram intrépidas e que apregoaram que na escola não só se ensina, mas se educa e que a verdadeira educação deve ter Deus por base e que num país católico, entranhadamente católico e que à Religião Católica se ligam os seus feitos e a sua civilização, se deve falar de Jesus e de sua doutrina. (A CRUZADA, jan. 1928, p. 198-199)

Em 1928, o grupo católico manifestava-se a respeito do significado da ação da Primeira Conferência Nacional de educação realizada no Paraná pela ABE:

Honra lhes seja a esses que de fronte erguida professaram sua fé numa assembléia em que estavam representados todos os Estados da Nação e prestaram ao nosso Brasil mais este benefício, apoiando e disseminando um alvitre que, esperamos, há de ser dentro em breve uma viva realidade, alvitre que se resume nestas palavras: Deus na escola (A CRUZADA, jan. 1928, p. 199).

Essa passagem refere-se à Conferência Nacional de Educação, realizada em Curitiba, em dezembro de 1927. Para o laicato católico esse evento significava a possibilidade de o seu projeto ser exposto entre a intelectualidade brasileira que estava interessada em discutir a temática educacional. Não obstante, segundo Carvalho, a Primeira Conferência:

Teve restrita participação de delegações estaduais, confinando-se preponderantemente ao círculo educacional paranaense. Caracterizou-se, comparada à Segunda, por não serem as teses nela defendidas ainda representativas de grupos ou tendências do movimento, mas apenas a expressão da posição de seus defensores (CARVALHO, 1998, p. 64). 
De acordo com a pesquisa de Maria Auxiliadora Schmidt (1997), os participantes da Primeira Conferência constituíram um total de 527. Desse número, 504 representavam o estado do Paraná. Os temas da Primeira Conferência discutiam as questões da unidade nacional, a uniformização do ensino primário, a criação de escolas normais superiores e a organização de instrumentos de aperfeiçoamento profissional e técnico.

Para o grupo católico do Paraná, essa Conferência teve enorme significado, pois Munhoz da Rocha, governador, e Lysimaco Ferreira da Costa, Inspetor Geral da Educação, e diversos intelectuais e professores paranaenses estavam presentes. A revista católica retratou essa conferência ao mencionar que:

Reuniu-se nesta capital de 19 a 25 de Dezembro o Primeiro Congresso nacional de Educação. Solenemente instalado no Teatro Guaíra pelo Presidente do Estado, Dr. Munhoz da Rocha, no dia 19, data da emancipação política do Paraná, o Congresso, sob a presidência do Dr. Carlos Barbosa de Oliveira e secretariado pelo Dr. Lysimaco Ferreira da Costa, reuniu no Congresso do Estado o escol do professorado que acompanhou com interesse e entusiasmo os trabalhos e deliberações (A CRUZADA, jan. 1928, p. 215).

Nessa Conferência, foi apresentada uma série de teses que versava sobre diversos temas, entre elas mereceu destaque nos periódicos católicos a tese de Amélia R. Martins, que discutia a questão do ensino religioso nas escolas públicas brasileiras. De acordo com Carvalho, nessa Conferência "é possível registrar a recepção de algumas propostas e uma questão polêmica: o ensino religioso" (CARVALHO, 1998, p. 311).

A polêmica em torno da questão religiosa foi veiculada na imprensa paranaense ligada aos livres-pensadores que protestavam a tese de Amélia Martins, que defendeu o retorno do ensino religioso nas escolas públicas. A Gazeta do Povo expressou a decepção do grupo anticlerical em relação ao evento, particularmente no que diz respeito à tese que defendia a educação religiosa nas escolas oficiais. Essa tese foi rejeitada quando foi à votação na Assembleia. No entanto, essa situação foi revertida pela intervenção de Lysímaco Ferreira da Costa, que ressaltava o significado da religiosidade na instrução. Segundo Carvalho, "em sua versão original, a tese da educadora reincidente propunha o ensino religioso nas escolas primárias públicas, fundado na doutrina católica” (p. 313). O grupo anticlerical conseguiu, entretanto, com um substitutivo de 
Lourenço Filho, modificar a tese, que passava a ter base na noção de Deus, mas não fundada na doutrina católica. Com essa estratégia, o grupo dos livres-pensadores minou o projeto dos católicos que queriam estabelecer, a partir da ABE, o retorno do ensino religioso católico nas escolas públicas. Retirar a religião católica e colocar em seu lugar a noção de Deus representou uma enorme mudança, pois o que estava em disputa era o domínio das principais esferas públicas e privadas do país entre os católicos e os anticlericais.

\section{Ensino religioso facultativo no Decreto n. 19.941 de 1931: o brado retumbante dos católicos}

Com a República a Igreja perdeu alguns privilégios, entre os quais destacamos o direito de ensinar a religião nas escolas públicas. Para retomar esse direito, a Igreja Católica procurou eleger/apoiar governantes que se comprometessem com seus interesses e organizou a Ação Católica.

Para a Igreja Católica, a implantação de uma escola laica significava perder espaços na sociedade moderna. Portanto, não se tratava, simplesmente, de incluir ou excluir o ensino religioso nas escolas, mas sim de preservar espaços para si no cenário cultural brasileiro e paranaense. Os católicos afirmavam que o presente estava passando por uma séria crise moral. Essa foi uma postura comum entre os diversos grupos que estavam em disputa no cenário cultural brasileiro/paranaense. Essa situação está presente na obra de Carvalho: "o presente é reiteradamente condenado e lastimado, sendo caracterizado de modo a fundamentar temores de catástrofes iminentes, que atingiriam o país se a campanha não obtivesse os resultados desejados" (CARVALHO, 1998, p. 140-141). Ao contrário, sugere a autora, "o futuro é insistentemente aludido como dependente de uma política educacional: futuro de glórias ou de pesadelos, na dependência da ação condutora de uma 'elite' que direcione, pela educação, a transformação do país” (p. 141). Essa estratégia discursiva apareceu entre o laicato católico paranaense, quando este afirmava que a religião católica deveria ser o elemento necessário para a restauração da nação.

Os grupos que disputavam os espaços das diversas instituições privadas e públicas no Paraná postulavam elementos comuns, entre os quais destacamos o reconhecimento de que uma elite intelectual deveria 
dar as diretrizes para a sociedade, a crença de que era preciso formar a nacionalidade e a expectativa de que a educação seria o grande instrumento de moldagem dos brasileiros. Não obstante, esses grupos propunham medidas diferenciadas para alcançar essas metas. Os católicos acreditavam que a religião seria o instrumento fundamental para a constituição da ordem brasileira. Os anticlericais negavam esse poder concedido à religião e postulavam que a sociedade poderia se estruturar a partir de uma racionalidade laica. O grupo católico acreditava que o futuro consistia no retorno dos elementos religiosos que, no passado, estiveram presentes na sociedade brasileira e que, no presente, foram excluídos das esferas públicas. Nesse sentido, afirma Carvalho que os católicos visavam ao "resgate de um 'Brasil unido', legado de antepassados guardiões da Ordem, que a Federação e a 'ilusão de conquistas democráticas' ameaçavam desmembrar" (CARVALHO, 1998, p. 310).

Alguns dias antes do decreto de Francisco Campos, os jornalistas católicos reafirmavam o sentido do ensino religioso na escola:

O fim essencial da escola é não só instruir mas educar, não habilitar técnicos senão também formar homens que na vida doméstica, profissional e cívica sejam cumpridores fieis de todos os seus deveres. Não é possível impor preceitos a consciência e subministrar à vontade motivos eficazes de ação fora de uma concepção ético-religiosa da vida; formar o homem é orientá-lo para atingir a perfeição de sua natureza e realizar a plenitude dos seus destinos, e de qualquer atitude em face das questões da natureza e dos destinos humanos envolve, implícita ou explicitamente, uma solução do problema religioso; a neutralidade educativa, é um erro pedagógico e uma impossibilidade pratica, e Educação neutra, isto é, educação nula. Ao Estado cumpre respeitar o direito natural dos Paes de dirigir a educação dos filhos, não impondo uma criança aos que a ela se não querem submeter, mas também não constrangendo a um ensino agnóstico os filhos das famílias religiosas, cuja liberdade de consciência o Estado não pode violar. O Brasil nasceu católico; sob a influencia do catolicismo se formou a nossa nacionalidade, e católica é ainda na sua quase totalidade a população brasileira (A CRUZADA, 12 abr. 1931, p. 02).

O decreto de Francisco Campos recebeu dos jornalistas católicos paranaenses uma série de manifestações favoráveis. Com o decreto, ficou "facultado nos estabelecimentos de instrução primária, secundaria e normal, o ensino da religião" (A CRUZADA, 10 maio 1931, p. 01). O grupo católico dirigiu moções ao ato do governo de Getúlio Vargas. Ao contrário, os anticlericais passaram a criticar as medidas tomadas pelo 
governo de Vargas. O comprometimento de Francisco Campos com o ideário católico estava presente, de acordo com Cury, em seus discursos de posse do Ministério de Educação e Saúde Pública, ao afirmar que:

Os valores religiosos, em especial, são os únicos a satisfazer a 'fome do eterno' existente no homem incapaz de ser saciada com filosofias liberais e 'concepções de mundo sedizentes científicas'. Além da fidelidade ao voto da fundação do Brasil, e da satisfação ao que de eterno existe no homem, os valores espirituais representam um dique ao avanço do comunismo (CURY, 1988, p. 104).

Segundo Cury (1988, p. 108), existem quatro motivos que justificavam o decreto que restabeleceu o ensino religioso nas escolas públicas:

O fim da escola é educar, isto é, formar o homem. Não é possível formar o homem sem uma concepção ético-religiosa da vida. Uma concepção éticoreligiosa da vida não pode ser ditada pelo Estado, especialmente se este for leigo, pois violaria o direito natural dos pais quanto à educação dos filhos. $\mathrm{O}$ ensino religioso, determinado pela vontade das famílias, impõe-se portanto, como dupla necessidade de uma exigência pedagógica, e de um respeito jurídico às liberdades espirituais dos cidadãos.

Em artigo intitulado "A lei do ensino religioso e os agnósticos", o laicato católico condenou os anticlericais por terem criticado o decreto que facultou o ensino religioso nas escolas públicas. O grupo escrevia que tão logo o governo federal acenou para o retorno do ensino religioso às escolas oficiais, os anticatólicos esboçaram suas críticas. Além disso, asseverava: "é curioso como certa gente tem a compreensão do bem publico; quer a liberdade para si, e cerceia-na aos outros" (A CRUZADA, 10 maio 1931, p. 01).

O grupo católico considerava a Primeira República anticlerical. A principal razão dessa denominação se devia à separação entre Estado e Igreja Católica. Ao longo desse período, a Igreja Católica organizou-se e passou a lutar para reconquistar alguns direitos que havia perdido com a Constituição de 1891, entre eles o retorno da educação religiosa nas escolas oficiais. A ação de Francisco Campos significou uma vitória parcial dos católicos sobre os livres-pensadores. O grupo católico não abandonou seu projeto de resgate de um Brasil unido, ou melhor, de constituição de uma nação católica. 
O grupo anticlerical organizou uma série de atos com o objetivo de contrapor-se ao poder da Igreja Católica. Rosário Farâni Mansur Guérios condenou a ação dos livres-pensadores paranaenses que se posicionaram contrários ao decreto que facultou o ensino religioso nas escolas. Sobre esse aspecto, emendou:

O Teatro Guaíra desta capital foi Terça-feira última transformado em salão de insultos grosseiros à Igreja Católica por parte de gente que proclama orgulhoso e alto a liberdade de consciência. A caterva dos anticlericais resolveu reunir-se para combater o decreto facultativo e sumariamente liberal do ensino religioso nas escolas primárias e secundárias (A CRUZADA, 10 maio 1931, p. 02).

Os católicos acreditavam que travavam uma disputa do bem contra o mal. Nessa direção, afirma Cury:

A cosmovisão católica entende o confronto mais do que uma luta a fim de reintroduzir o ensino religioso e outros pontos na Constituição e mais do que a própria aplicação real destes princípios. Trata-se de uma luta entre o Bem e o Mal, cujo pertencer a um ou outro é ditado pela atitude que se tem em face dos grandes princípios explicativos da realidade (CURY, 1988, p. 130).

O laicato católico atacou os anticlericais ao afirmar que:

Continuam comentários, aprovações e protestos a respeito do ensino religioso nas escolas oficiais. É curioso de ver certas agremiações, absolutamente amorfas de senso religioso, levantar-se contra a aplicação larguíssma de um direito. No Brasil, e para o brasileiro, só conhecemos uma religião, a católica (A CRUZADA, 17 maio 1931, p. 01).

O grupo católico condenou a iniciativa dos livres-pensadores que pediam a exoneração do Ministro Francisco Campos, em razão do decreto do ensino religioso facultativo. $\mathrm{O}$ texto a seguir sustenta que:

É simplesmente lamentável ver-se cidadãos que ocupam cargos de confiança do governo, pretenderem ao menos com palavras amotinar algumas classes de indivíduos a fim de combater a lei que veio em nome da verdadeira liberdade de consciência livrar o Brasil do laicismo pernicioso que durante quarenta anos de vida republicana tão maus frutos produziu (A CRUZADA, 24 maio 1931). 
Para os livres-pensadores, esse ato do então ministro contradizia os princípios da República, como, por exemplo, a separação entre Estado e Igreja, que estava presente na Constituição. A esse respeito afirma Cury: “os Pioneiros criticam o decreto, justificando-se na sua inconstitucionalidade" (CURY, 1988, p. 109). O laicato católico, por sua vez, entendia que essa atitude contra o ministro tratava-se de um absurdo. Ao contrário, o ato de Francisco Campos deveria ser comemorado, pois livrara a sociedade brasileira do laicismo que vinha se estabelecendo desde a República. Não obstante, o grupo católico não estava inteiramente satisfeito, pois lamentava:

Que as conclusões das premissas da exposição de motivos de Campos não são lógicas. Elas não falam em Igreja Católica especificamente e nem em Jesus Cristo, além disto lamenta a aplicação do decreto em alguns Estados como sendo lesiva aos seus objetivos e pouco resguardada pelo aparato oficial do Estado. Vargas teria sido o mero porta-voz de um direito do povo católico, profundamente religioso e ligado ao único Senhor das coisas (CURY, 1988, p. 109-110).

Para os católicos, era preciso esclarecer a opinião pública de que:

O ensino religioso é fa-cul-ta-ti-vo! como é que uma coisa que é facultativa, que pode ser aceita ou não, à vontade dos interessados, pode constituir lesão, diminuição da liberdade? Ponto facultativo, nas repartições publicas, não é ponto livre? Aqui o homem caiu em si e compreendeu o contra senso que havia em combater uma coisa facultativa e livre em nome da liberdade (A CRUZADA, 19 julho 1931, p. 01, grifo do autor).

Para o laicato católico, os livres-pensadores abusavam da opinião pública ao retratarem, de maneira equivocada, os elementos presentes no decreto que restabeleceu o ensino religioso nas escolas públicas. Para ele:

Só a má fé é capaz de levantar-se contra uma medida tomada pelo bom senso que quer corrigir os erros passados e restituir à Religião do seu papel de educadora do povo, de mobilizadora da sua consciência e do seu coração, para o realçar em toda a sua dignidade moral, para reintegrá-lo nos seus direitos sagrados (A CRUZADA, 10 maio 1931, p. 01).

O confronto entre católicos e anticlericais se afunilou na medida em que foi instalada a Assembleia Nacional Constituinte, em 1933. Segundo Cury (1988, p. 113), 
O grupo renovador estava praticamente garantido na sua representação, já que como 'técnicos', desempenhavam importante papel na burocracia estatal e conseqüentemente nos projetos e ante-projetos enviados à ANC. Além disso, tinham a seu favor, direta ou indiretamente, republicanos com o espírito de 1891, anticlericais, católicos liberais, representantes de outros credos, da maçonaria e mesmo os de esquerda.

Por outro lado, "o grupo católico era majoritário e veio com posições definidas e de certo modo garantidas” (p. 113). Na Constituição de 1934, o grupo católico conseguiu estabelecer o ensino religioso facultativo nas escolas públicas.

\section{Considerações finais}

O objetivo deste artigo consistiu em discutir a ação e os discursos dos intelectuais católicos em defesa da inclusão do ensino religioso nas escolas públicas paranaenses e brasileiras, enfatizando suas intervenções na arena política (parlamento) e na esfera cultural (imprensa). A ação política foi discutida a partir da atuação do deputado Alcidino Pereira, representante do clero católico, particularmente o projeto de lei apresentado no Congresso Legislativo Paranaense visando a instituir o ensino religioso facultativo nas escolas públicas e nas escolas privadas subvencionadas pelo erário público. No plano cultural, esta narrativa privilegiou a atuação da revista $A$ Cruðada como principal responsável pela divulgação da posição católica e de combate aos anticlericais.

$\mathrm{Na}$ tribuna parlamentar, o confronto entre Alcidino Pereira e Azevedo Macedo é exemplar para sintetizar os sentidos dos projetos societários e educativos que o grupo católico e o grupo anticlerical postulavam ao longo da década de 1920. Tal disputa reatualizava o movimento internacional e nacional da Igreja Católica de combate ao laicismo, bem como o movimento dos livres-pensadores, ou melhor, do grupo que propugnava um etos livre das amarras do catolicismo. A discussão sobre o ensino religioso é o espelho da confrontação entre duas concepções societárias que, em muitos aspectos, eram opostas. A rigor, essas acepções expressavam duas filosofias antagônicas: filosofia transcendental e filosofia naturalista. Entretanto, a divergência não residia apenas no plano do conhecimento, mas particularmente na esfera do poder. Em termos pre- 
cisos, em nome de determinada verdade, tais grupos visavam a legitimar suas intervenções culturais e políticas na vida societária. $\mathrm{Na}$ arena parlamentar, objetivam transformar seu poder em força política, isto é, determinar, por meio do aparato jurídico, a organização da educação e da própria sociedade. É nesses termos que se interpretou o debate na tribuna do congresso paranaense entre os deputados denominados acima.

A imprensa católica expressa uma das estratégias da Igreja que visava a conformar sua visão de mundo entre uma parcela de letrados da capital do Paraná. Essa ação tem um caráter cultural, ou seja, objetiva dar publicidade ao modo de pensar, de ser, de agir e de sentir da cosmovisão católica. Ao contrário da ação política (força da lei), a ação cultural se estrutura pela força do convencimento - lugar por excelência do poder simbólico que, na acepção de Bourdieu, "é, com efeito, esse poder invisível o qual só pode ser exercido com a cumplicidade daqueles que não querem saber que lhe estão sujeitos ou mesmo que o exercem" (BOURDIEU, 2002, p. 8). Na imprensa católica, atuavam os principais representantes do clero e do laicato de Curitiba, os quais exerciam o papel de mediadores culturais, pois se mostravam portadores da capacidade "de construir o dado pela enunciação, de fazer ver e fazer crer, de confirmar ou de transformar a visão do mundo e, deste modo, a ação sobre o mundo, portanto o mundo" (p. 14). Eles exerciam o "poder quase mágico que permite obter o equivalente daquilo que é obtido pela força [...], graças ao efeito específico de mobilização [...]" (p. 14). Tal poder somente se exerce "se for reconhecido, quer dizer, ignorado como arbitrário" (p. 14). É nesse sentido que se compreendeu a atuação do grupo católico na revista $A$ Cruzada.

Portanto, a intervenção na tribuna parlamentar paranaense e na revista $A$ Cruzada evidencia a própria ação da Igreja Católica que transitava da arena cultural à arena política. O projeto romanizador da Igreja Católica estava direcionado para a política - apoio eleitoral aos candidatos comprometidos com os interesses confessionais (Liga Eleitoral Católica) e para a cultura - criação de centros culturais, periódicos, escolas, institutos, faculdades e universidades (Centro Dom Vital, Círculo de Estudos Bandeirantes, A Ordem, A Cruzada). 


\section{REFERÊNCIAS}

BOURDIEU, P. O poder simbólico. Rio de Janeiro: Bertrand Brasil, 2002.

CAMPOS, N. de. Laicato católico: o papel dos intelectuais no processo de organização do projeto formativo da igreja católica no Paraná (1926-1938). Dissertação (Mestrado em História da Educação) - UFPR, Curitiba, 2002.

CARVALHO, M. M. C. de. Molde nacional e fôrma cívica: higiene, moral e trabalho no projeto da Associação Brasileira de Educação (1924-1931). Bragança Paulista: EDUSf, 1998. CURY, C. R. J. A educasão na revisão constitucional de 1925-1926. Bragança Paulista: EDUSF, 2003.

CURY, C. R. J. A educação na revisão constitucional de 1926. In: FÁVERO, O. (Org.). A educação nas constituintes brasileiras (1823-1988). Campinas: Autores Associados, 1996.

CURY, C. R. J. Estado e educação na revisão constitucional de 1926. Educação e sociedade, Campinas, n. 55, p. 238-262, ago. 1996.

CURY, C. R. J. Ideologia e educação brasileira: católicos e liberais. São Paulo: Cortez, 1988.

DIAS, R. A doutrina católica sobre a autoridade no Brasil (1922-1935). Tese (Doutorado) Unicamp, Campinas, 1993.

MACEDO, A. Parecer da comissão de constituição e justiça do congresso legislativo do estado. . In: PEREIRA, A. Projeto n. 40 apresentado ao Congresso Legislativo Paranaense. Guaranésia (MG): Typografia e papelaria Commercial, 1922, p. 13-20.

PEREIRA, A. Discurso com o qual o deputado Alcidino Pereira justificou seu projeto instituindo o ensino religioso facultativo nas escolas. In: PEREIRA, A. Projeto $n^{\circ} .40$ apresentado ao Congresso Legislativo Paranaense. Guaranésia (MG): Typografia e papelaria Commercial, 1922, p. 5-12.

PEREIRA, A. Refutação do parecer da comissão de constituição e justiça. In: PEREIRA, A. Projeto $n^{\circ} .40$ apresentado ao Congresso Legislativo Paranaense. Guaranésia (MG): Typografia e papelaria Commercial, 1922, p. 21-35.

REVISTA A CRUZADA, Curitiba, 1926-1931.

SCHMIDT, M. A. M. dos S. Infância: sol do mundo. A primeira conferência nacional de educação e a construção da infância brasileira. Tese (Doutorado em História) - UFPR, Curitiba, 1997. 


\section{NOTAS}

1 Chamamos de público leitor médio aqueles indivíduos que construíam suas formas avaliativas a partir da imprensa. Portanto, não pertenciam aos círculos esotéricos que se dedicavam aos estudos filosóficos e teóricos.

2 Alcidino Pereira assumiu a função de deputado pelo Partido Republicano. Este partido tinha forte apoio dos católicos. Naquele momento, o governo do Paraná estava sob a direção de Caetano Munhoz da Rocha, uma das principais lideranças desse partido. Munhoz da Rocha era um forte aliado da Igreja Católica paranaense.

3 Em junho de 1922, esses pronunciamentos foram publicados pelo Padre Alcidino Pereira sob o título "Projeto n. 40 apresentado ao Congresso Legislativo Paranaense", na Tipografia e Papelaria Comercial da cidade de Guaranésia, Minas Gerais. O primeiro discurso foi transcrito do jornal $A$ República de 20 de março de 1922. O segundo foi transcrito do jornal Comércio do Paraná de 28 de março de 1922. O terceiro foi transcrito do jornal $A$ República de 31 de março de 1922. As indicações das citações serão feitas pela obra publicada.

4 Naquele contexto, os seguintes estados brasileiros já tinham incluído o Ensino Religioso facultativo: Ceará, Minas Gerais, Rio Grande do Sul, Sergipe, Pernambuco e Santa Catarina.

$5 \mathrm{O}$ ataque ao qual Alcidino Pereira se refere foi promovido pela imprensa anticlerical da capital do Paraná (Comércio do Paraná, Diário da Tarde e Gazeta do Povo).

6 Em 1926, era Diretor da Escola Normal Secundária do Paraná; em 1929, fez parte do grupo fundador do Círculo de Estudos Bandeirantes (órgão de estudo da doutrina católica e de formação do laicato). 
